\title{
Pythagoras goes Open Access at www.pythagoras.org.za
}

\author{
Author: \\ Alwyn Olivier ${ }^{1,2}$ \\ Affiliations: \\ ${ }^{1}$ Editor-in-Chief, Pythagoras \\ ${ }^{2}$ Research Unit for \\ Mathematics Education, \\ University of Stellenbosch, \\ South Africa \\ Correspondence to: \\ Alwyn Olivier \\ Email: \\ aio@sun.ac.za \\ Postal address: \\ Private Bag X1, \\ Matieland 7602, \\ South Africa \\ How to cite this article: \\ Olivier, A. (2011). Pythagoras \\ goes Open Access at \\ www.pythagoras.org.za. \\ Pythagoras, 32(1), \\ Art. \#48, 2 pages. http:// \\ dx.doi.org/10.4102/ \\ pythagoras.v32i1.48
}

C 2011. The Authors. Licensee: AOSIS OpenJournals. This work is licensed under the Creative Commons Attribution License.
The publication of this issue of Pythagoras finally realises the goals I envisaged for Pythagoras in my 2008 editorial, titled "Pythagoras is going places ..." (Olivier, 2008): Pythagoras is now formally an Open Access journal, freely accessible online for anyone to read, download and distribute.

What I anticipated then was a do-it-yourself job where we would upload Pythagoras articles on our own do-it-yourself website (the so-called 'green route'), because the increased costs of outsourcing the production of Pythagoras to a professional publishing house (the so called 'golden route') (Harnard et al., 2008) would make it impossible for AMESA (Association for Mathematics Education of South Africa) to continue offering print-issues of Pythagoras as a 'free' benefit to members. However, we soon realised that real open access was only really possible with a professional publisher. So we went out and found the money and the publisher - Pythagoras is now formally published by African Online Scientific Information Systems (AOSIS) OpenJournals Publishing, and the print edition is still free to members.

If you are reading the print-issue, I hope that you will agree that it looks much more professional than before! If you are reading this online, I trust that you appreciate the many other benefits of the website (searching, indexing, etc.). And if you are an author, I trust that you will soon reap the benefits of being read more widely and cited more often.

\section{The golden route to Open Access}

The primary purpose of Pythagoras as an AMESA research journal is as a service to the scholarly community to support them to get their research published and available to the wide community.

Merely posting an article on the Internet does not mean that many people are going to find it and read it. However, by publishing through the AOSIS OpenJournals platform, articles in Pythagoras become much more discoverable, because the publisher has links to Google Scholar, Crossref, Directory of Open Access Journals, et cetera. That means that when somebody searches for a key word, the probability that relevant Pythagoras articles are listed and accessed is now much higher.

The golden route Open Access model therefore first and foremost means better support for our authors, making their research universally accessible and discoverable, so their work is available to a larger audience, more people can read their work, so they can make a bigger impact in the research community, Africa and internationally, and they may be cited more often.

Another benefit of the golden route is that only publishers may assign a so-called digital object identifier (DOI) to each article. The DOI for a document is permanent, whilst a uniform research locator (URL) may not be, therefore referring to an online document by its DOI provides more stable linking than simply referring to it by its URL.

Using the 'rolling publication' model, an article is published online the moment it is finished, before it is later compiled with other articles into an issue and printed. It means that one's research is made available more quickly.

Furthermore, the whole submission-review-edit-publish cycle is handled online through a manuscript management system and is supported by professional AOSIS administrative staff. This frees the editor to concentrate on his academic role of engaging with authors and reviewers about the substance of submitted manuscripts. This is the way it should be!

\section{Open Access is not free}

Open Access means that it is free to the reader. Authors retain copyright through a Creative Commons Attribution License, so there are no legal barriers. However, golden route Open Access is not free to publish, free to maintain or free to print! This change in publishing model has serious 
financial implications for AMESA. AMESA is carrying the full costs in 2011, but will introduce a publishing fee in 2012, where the authors (meaning their institutions) will pay $50 \%$ of the publishing costs. We believe such a business model will make our Open Access publishing economically feasible and robust.

\section{Forward}

It has been a long and arduous road from deciding to go Open Access, to researching different options, negotiating a contract, securing funding, developing the website, getting to know the manuscript management system, supporting authors and reviewers to handle the manuscript management system, et cetera. But it has been worthwhile! I would like to thank the AMESA Council and the Pythagoras Editorial Board for their support in following this route.

Now that we have established a sound infra-structure for Pythagoras, we can address other means of support, that is, to support our authors in the writing process. Our editorial team and reviewers are already playing an important role in helping authors to improve their manuscripts to get it publishable. We have now started a project in terms of supporting authors and reviewers through writing workshops at AMESA congresses, as well as helping authors and reviewers with different aspects of the writing and reviewing process.

I believe that through its support for authors and reviewers, Pythagoras can play a role in the professional development of our mathematics education community, and I look forward to developing this role in the next few years.

\section{References}

Harnad, S., Brody, T., Vallieres, F., Carr, L., Hitchcock, S., Gingras, Y., et al. (2008). The access/impact problem and the green and gold roads to Open Access: An update. Serials Review, 34(1), 36-40. http://dx.doi.org/10.1016/j.serrev.2007.12.005

Olivier, A.I. (2008). Pythagoras is going places ... Pythagoras, 68, 2.

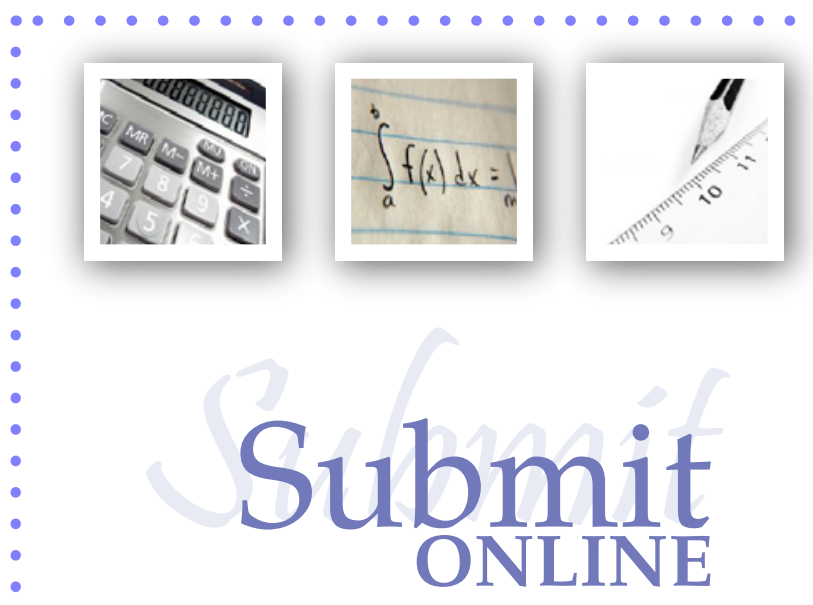

Pythagoras is now open access and welcomes manuscript submissions online at http:/ / www.pythagoras.org.za.

Pythagoras is an influential, frequently cited, accredited, peer reviewed journal published since 1980. The journal provides a forum for the presentation and critical discussion of current research and developments in Mathematics Education at national and international level.

What is availible at http://www.pythagoras.org.za? Full content of the printed edition of the Pythagoras, made available in advance.

Full, searchable articles in PDF, HTML, XML and ePUB formats. Complete back issues to the year 2009, all in searchable formats with more to follow.

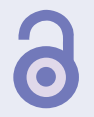

We invite you to subscribe - FREE of charge - to our electronic Table of Contents service and receive the full Table of Contents on the day of publication, directly to your email inbox. All articles are listed via live links, so you will always be just one click away from any article!

We invite and welcome

submissions to Pythagoras that significantly contribute to our understanding of mathematics teaching, learning and curriculum, including reports of original research and theoretical perspectives. We also invite referees that would be willing to act as reviewers

on this original content to advise the Editor on the scholarly merits of manuscripts and to help authors to improve their work.

\section{Visit \\ http:/ / www.pythagoras.org.za}

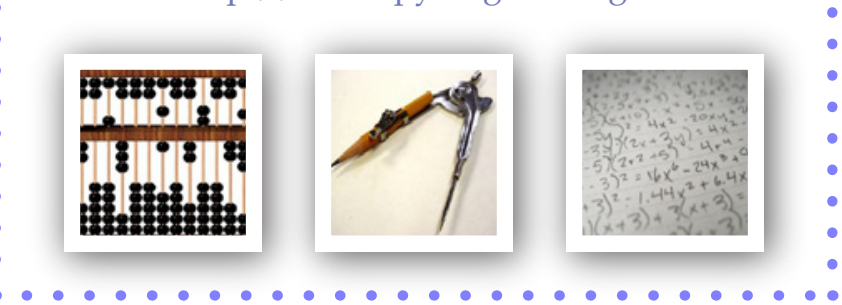

